Archived version from NCDOCKS Institutional Repository http://libres.uncg.edu/ir/asu/

\title{
Appalachľan
}

B O O N E, NORTH CAROLIN A

\section{The Economic Impact And Civic Pride Effects Of Sports Teams And Mega-Events: Do The Public And The Professionals Agree?}

\author{
By: Peter A. Groothuis and Kurt W. Rotthoff
}

\begin{abstract}
Often sports leagues, organising committees, and team owners justify the use of public funds to build sports stadiums by the perceived economic impacts and civic pride generated by the teams or mega-events. Since the 1980s many economic studies have examined the economic impact and civic pride created by professional sports teams. Most of the economic literature finds sports teams or mega-events have little or no economic impact, but there are mixed findings on the magnitude of civic pride. Overall, most of the economic literature suggests that the benefits created by sports teams or events do not outweigh the cost of public subsidies provided. We conduct a survey of public opinion on US residents' perceptions of economic impacts and civic pride benefits from mega-events such as the Super Bowl and the Winter Olympics. Our study asks the question: Do residents believe that mega-events and sports teams generate positive economic impacts and civic pride or not? We find that, like economists, the public doubts that public funding of mega-events is a good idea.
\end{abstract}

Groothuis, P. A., and Rotthoff, K. W. (2016) The Economic Impact and Civic Pride Effects of Sports Teams and MegaEvents: Do The Public and the Professionals Agree?. Economic Affairs, 36: 21-32. doi: 10.1111/ecaf.12156. Publisher version of record available at: https://onlinelibrary.wiley.com/doi/epdf/10.1111/ecaf.12156 


\title{
THE ECONOMIC IMPACT AND CIVIC PRIDE EFFECTS OF SPORTS TEAMS AND MEGA-EVENTS: DO THE PUBLIC AND THE PROFESSIONALS AGREE?
}

\author{
Peter A. Groothuis and Kurt W. Rotthoff*
}

\begin{abstract}
Often sports leagues, organising committees, and team ownersjustify the use of public funds to build sports stadiums by the perceived economicimpacts and civic pridegenerated by theteams or mega-events. Sincethe 1980s many economic studies have examined the economicimpact and civic pridecreated by professional sports teams. Most of the economic literature finds sports teams or mega-events havelittleor no economicimpact, but therearemixed findings on themagnitudeof civicpride. Overall, most of theeconomic literature suggests that the benefits created by sports teams or events do not outweigh the cost of public subsidies provided.Weconducta survey ofpublicopiniononUSresidents' perœetionsofeconomicimpactsand civicpridebenefitsfrom mega-events such as theSuper Bowl and theWinter Olympics. Our study asks thequestion: Do residentsbelievethat mega-events and sports teams generate positiveeconomicimpacts and civic pride or not? Wefind that, likeeconomists, thepublic doubts that public funding of mega-events is a good idea.
\end{abstract}

JEL codes: L83, Z2, Z21.

Keywords: civic pride; economic impact; sport stadiums; stadium financing.

\section{Introduction}

Public funding is commonly used to subsidise stadium construction and to support sporting events. For instance, since 1995 over 100 sports facilities have opened in the United States, with the majority receiving direct public funding. The owners of sports teams justify public funding by arguing that sports teams (a) generate a local economic impact by creating jobs and by increasing local incomes, and (b) provide civic pride and intangible benefits to the host community. Eckstein and Delaney (2002) suggest that local elites, in order to gain public support, promote ideas such as community self-esteem and community collective conscience to help them reap large amounts of public subsidy for their private stadiums.

Economists have analysed both of these arguments. When it comes to the economic impact of sports teams, one of the most studied topics in the sports world, economists have consistently found that sports stadiums do not have a local economic impact. This contradicts economic impact estimates sponsored by teams and politicians who support the use of public funds, primarily because these estimates misapply the analysis of economic impact (see Crompton 1995). When it comes to intangible benefits of civic pride, the results have been mixed. Using various techniques, economists find that sport teams do provide public good benefits but generally the benefits do not justify the entire public funds provided. 
In our study, we provide a literature review of both the economic impact and the civic pride benefits of sports teams to gain insights into the justification of public funding. We then match a survey of the literature to a public opinion poll conducted across the United States to see whether the responses match the findings in the literature or whether the general public is influenced by media campaigns to justify public spending.

In general, we find that people do not know, or soon forget, who has hosted the Super Bowl or the Olympics. We also discover that almost all respondents do not plan to visit cities or countries that have hosted the Super Bowl or the Olympic Games. In addition, however, we find that people believe that having a professional sports team in a city enhances the image of that city and that hosting an Olympics enhances the image of the host county. Overall, we establish that public opinion does correlate with the findings in the economic literature.

\section{Economic impact}

The economic impact of sports has been studied in two main ways: through local economic impact and through the impact of mega-events. Both areas of study are summarised below.

\subsection{The economic impact of having a local professional sports team}

The impact of having a professional sports franchise has been widely studied. Baade and Dye (1988, 1990) look at the impact a franchise has on retail sales and aggregate income within given Metropolitan Statistical Areas (MSAs). Their 1988 paper shows some support for a link between major league sports and manufacturing activity. In their 1990 study they find that in a small fraction of cases manufacturing activity increases with a new or renovated stadium. They conclude, however, that the measurable economic benefits are not large enough to justify stadium subsidies. Baade (1996) looks at a professional sports team's ability to create jobs, and again fails to observe a positive correlation. Zimbalist and Noll (1997) find that sports teams and facilities are not a source of local economic growth and employment, and that the net subsidy exceeds the financial benefit of a new stadium. Baade and Sanderson (1997) find that nine cities experience a significant impact from the presence of a professional sports team. Interestingly, of the nine cities five experienced a positive impact and four a negative impact.

Coates and Humphreys (2003) measure the impact on many different sectors of the economy and find a small positive effect in one sector, namely amusement and recreation. They do, however, find an offsetting decrease in earnings and employment in the other sectors, suggesting that a substitution effect occurs between sectors. Their results support the idea that franchises do not create employment and income but shift consumption from one sector to another. The failure to find an economic impact is confirmed at the more local level by Jasina and Rotthoff (2008), who use county-level data rather than data from the larger MSAs. Coates and Depken (2009) look at four mid-sized cities in Texas with universities that play in the Football Bowl Subdivision of the US National Collegiate Athletic Association Division, and do not detect any evidence supporting the public subsidies for stadiums.

There is one study that shows a positive economic impact: Santo (2005) finds that the sport-specific urban stadiums built in the 1990s do justify public subsidies. Agha (2013) finds that minor league stadiums, which tend to be found in smaller communities, do indeed create 
a positive economic impact. She notes, however, that she does not look at the cost of building a stadium; so no benefit-cost conclusion can be drawn from her work. Hudson (2001) in a meta-analysis finds that how researchers treat local expenditures in their analysis accounts for the large variance in economic impacts.

\subsection{The economic impact of hosting a mega-event}

Although little or no evidence of an economic impact of having a sports team in a community has been found, there is an argument that mega-events, such as the Super Bowls, Olympics, and World Cups, have a positive impact on the economies of mega-event hosts. It is argued that mega-events are expected to increase tourism, both current and future, as well as overall spending in the area. These events, however, may not have a positive impact if there is a crowding-out effect whereby they cause people who are not interested in them to avoid the area. Crowding out might also occur if mega-events cause non-sports sectors of the economy to shut down or become overcrowded (Preuss 2011).

Coates and Matheson (2011) find, from a panel of American cities from 1993-2005, that mega-events generally exhibit little impact on rental prices in a given city as a whole. In addition, when an impact is found it is just as likely to reduce rental prices as to increase them. Allmers and Maennig (2009) analyse the Fédération Internationale de Football Association (FIFA) World Cup matches in France (1998), in Germany (2006), and in South Africa (2010). They find that the World Cups held in France and Germany show no evidence of creating positive impacts on tourism, employment, and income. They do speculate, however, that the South Africa World Cup may have a different potentially beneficial impact given the developing aspects of the country. These results are consistent with Baade and Matheson (2004), who find no positive economic effects of the World Cup matches held in the United States in 1994. Hagn and Maennig $(2008,2009)$ analyse the 1974 and 2006 World Cup matches in Germany, and likewise detect no positive economic impacts.

Szymanski (2002) analyses the world's 20 largest economies over a 30-year period and finds that growth in countries involved in the World Cup is significantly lower. Ritchie and Smith (1991) find that the worldwide name recognition of Calgary, after hosting the 1988 Winter Olympics, was positive but short-lived. In addition, Teigland's (1999) research shows that after the 1994 Winter Olympic Games in Lillehammer 40 per cent of full-service hotels in the town went bankrupt. Soberg and Preuss (2007) advise that hosting major sports events can boost tourism but the additional revenues might not cover the cost of investment by the host destination. Lastly, Preuss (2007) suggests that measuring the legacies of mega sport events for future tourism needs to account for how spending on sports venues may have crowded out spending on other tourist amenities.

Overall, the results of the economic impact studies suggest that sport teams and mega-events have either a small or no effect on the local economy. Politicians and team owners, however, still use the economic impact argument to justify public funds for sport arenas and events. In section 3 we discuss the civic goods benefits derived from sports teams and events.

\section{Civic pride}

Additional studies have attempted to estimate the intangible benefits, such as civic pride, provided to cities hosting a sports team. Intangible benefits include the well-being an individual derives from the ability to watch a local game on television, read about it in the newspaper, and talk about it with 
friends and co-workers, or the pride generated from being in a 'major league' city. Burns (2014) applies social identity theory to the New Orleans Saints fan base during the 2009 Super Bowl-winning season to identify the civic pride generated as reflected in national, regional, and local publications.

These benefits are often considered important, but are difficult to value. Economists drawing on the environmental literature have used two techniques to value the public-good benefits. The first is the stated preference technique, using primarily the contingent valuation method. The second is the revealed preference technique, which uses existing markets such as the housing or labour market to analyse differences in prices that may reveal the benefits created by a sports team.

\subsection{Thecivicprideinhaving a local team}

One of the first applications of the contingent valuation method to public good amenities was undertaken by Johnson and Whitehead (2000), who focus on both a minor league baseball team and a new arena for the University of Kentucky basketball team in Lexington. Their analysis finds that the measured benefits of either project do not provide justification for public funding. Johnson et al. (2001) find that while the Pittsburgh Penguins, an ice hockey team, generate substantial civic pride, the value of this public good falls far short of the cost of the new arena. Groothuis et al. (2004), using the same data set, suggest that, even if a vast majority of residents receive civic pride benefits from sports teams in Pittsburgh, only a minority support public funding for building new sports arenas.

Owen (2006), based on a contingent valuation study of both Michigan and Minnesota residents, suggests thatalthough the aggregate willingness to pay amounts to less than the typical stadium funding, it is still large enough to be considered for public support. A contingent valuation study of the Jacksonville Jaguars in the US National Football League (NFL) undertaken by Johnson et al. (2007) finds that the overall benefits to the community amount to $\$ 36.5 \mathrm{~m}$, less than the funds Jacksonvilleallocated to the Jaguars. Fenn and Crooker (2009), analysing the publicgoodsgenerated by the Minnesota Vikings of the NFL, find that the benefits to the community warrant the stadium subsidy given to retain the team in Minnesota.

Whitehead et al. (2013), using a combination of the contingent valuation and travel cost techniques, find that the residents of Alberta, Canada, derive both significant use and non-use benefits from the Calgary Flames of the National Hockey League: up to C $\$ 82 \mathrm{~m}$ dollars a year. The authors do suggest, however, that some of the benefits can be captured in ticket pricing. Carlino and Coulson (2004) also use the revealed preference technique to measure the benefits of sports teams, using hedonics. They find that the increase in quality-of-life benefits captured in higher housing costs justifies public spending on NFL sports teams. However, Coates et al. (2006) reanalyse Carlino and Coulson's (2004) data with various specifications and find that their results are not robust and do not justify public subsidies of sports teams.

\subsection{The civic pridein hosting a mega-event}

Kavetsos and Szymanski (2008) find that hosting the Olympics, World Cup, or European Championships increases the happiness of residents of the European countries. From studies conducted over a 30-year period, they find significant and positive effects from the World Cup. Dohmen et al. (2006) also find that individual perceptions of economic prospects at both the personal level and the economy-wide level are affected by soccer outcomes. 
Walton et al. (2008) use the contingent valuation technique to measure the benefits of hosting the Olympics in London in 2012. Their results suggest that positive intangible effects are associated with the event, and residents outside of London are willing to pay towards Olympics funding. In addition, Atkinson et al. (2008) discover that respondents from the cities of London, Manchester, and Glasgow are willing to pay $£ 22, £ 12$, and $£ 11$ per head per year (for ten years) respectively for the 2012 Olympics. They also show that the aggregate willingness to pay for intangible impacts is in the region of $£ 2 \mathrm{bn}$.

Overall, the results of the intangible benefits literature on sports teams and events suggest that public goods do exist and there is a benefit to the community. Most studies, however, find that the benefits of the team, facility, or mega-event are significantly smaller than the public funds provided.

\section{Polling}

One area that has been little examined is how this research informs public opinion. The research suggests that the public funds provided for sports teams, facilities, and events are greater than the benefits to the community. To analyse what people think, we developed questions for a national poll on sports consisting of two surveys: one of opinions about the Super Bowl, and one of opinions about the Winter Olympics.

The Stillman School of Business at Seton Hall University runs the Seton Hall Sports Poll. We used this Sports Poll to undertake a nationwide survey, conducted by telephone, of adults dialed from samples of both standard landline and cell phones. ${ }^{1}$ Our data on people's opinions of the Super Bowl were collected between 30 September and 3 October 2013 (before the Super Bowl); of the 947 phone call respondents, 44 per cent were male and 56 per cent were female. Our data on people's opinion of the Winter Olympics were collected between 24 and 26 February 2014 (after the Winter Olympics were held); of 780 phone call respondents 44 per cent were male and 56 per cent were female. The responses for each sample came from 10,000 random numbers dialed from across the United States. The Super Bowl survey has a 9.47 per cent response rate; the Winter Olympics survey has a 7.8 per cent response rate. ${ }^{2}$ Although these response rates are low they are not uncommonly so for telephone surveys.

In both polls, the respondents were asked whether they were sports fans using the question: 'How closely do you follow sports?' Respondents were asked to choose one of four answers: 'Very closely', 'Closely', 'Not closely', and 'Not at all'. All survey participants in both surveys responded to this question. We report the answers for the Super Bowl in Table 1A and those for the Winter Olympics in Table 1B.

One unexpected result is that more respondents self-identified as sports fans after the Olympics than before the Super Bowl. It is possible that the Olympics attracts a greater amount of attention because of the large number of different events that appeal to a wide variety of fans and because it happens once every four years. For instance, when asked 'What sport would you say you enjoyed the most?', 27 per cent of males said hockey and 52 per cent of females said figure skating, while 29 per cent of youth aged 18-29 enjoyed snowboarding and 44 per cent of adults aged over 60 enjoyed figure skating.

In the Super Bowl sample, we asked the subset of respondents who follow sports a follow-up question: 'Which sport [baseball or the NFL] would you say you are more interested in?' The answers are shown in Table 2. 
Table 1A: Answers (\%) to the question 'How closely do you follow sports?'

\begin{tabular}{|c|c|c|c|c|c|c|c|}
\hline \multirow[b]{2}{*}{ Super Bowl } & \multicolumn{3}{|c|}{ Gender } & \multicolumn{4}{|c|}{ Age (years) } \\
\hline & All & Male & Female & $18-29$ & $30-44$ & $45-59$ & $60+$ \\
\hline Very closely & 16.7 & 26.7 & 7.6 & 13.3 & 16.5 & 22.9 & 13.5 \\
\hline Closely & 29.1 & 31.3 & 27.1 & 27.0 & 29.0 & 25.3 & 34.6 \\
\hline Not closely & 22.9 & 18.3 & 27.1 & 22.8 & 20.2 & 23.0 & 24.9 \\
\hline Not at all & 31.2 & 23.7 & 38.2 & 36.9 & 34.3 & 28.9 & 27.1 \\
\hline
\end{tabular}

Table 1B: Answers (\%) to the question 'How closely do you follow sports?'

\begin{tabular}{|c|c|c|c|c|c|c|c|}
\hline \multirow[b]{2}{*}{ Olympics } & \multicolumn{3}{|c|}{ Gender } & \multicolumn{4}{|c|}{ Age (years) } \\
\hline & All & Male & Female & $18-29$ & $30-44$ & $45-59$ & $60+$ \\
\hline Very closely & 22.9 & 30.0 & 14.9 & 28.5 & 20.9 & 20.2 & 18.3 \\
\hline Closely & 33.9 & 35.5 & 32.4 & 33.3 & 38.1 & 36.0 & 30.6 \\
\hline Not closely & 29.5 & 23.7 & 34.9 & 28.0 & 22.5 & 29.7 & 37.7 \\
\hline Not at all & 14.5 & 10.8 & 17.8 & 10.3 & 18.5 & 14.1 & 13.5 \\
\hline
\end{tabular}

Table 2: Answers (\%) to the question 'Which sport would you say you are more interested in?'

\begin{tabular}{lccccccr}
\hline & \multicolumn{3}{c}{ Gender } & \multicolumn{3}{c}{ Age (years) } \\
\cline { 2 - 5 } & All & Male & Female & $18-29$ & $30-44$ & $45-59$ & $60+$ \\
\hline Baseball & 30.2 & 31.4 & 28.8 & 23.5 & 30.1 & 32.3 \\
NFL & 59.6 & 59.4 & 59.9 & 71.8 & 65.3 & 54.7 & 51.8 \\
Don't know/Refuse to answer & 10.2 & 9.2 & 11.3 & 4.7 & 4.5 & 13.0 \\
\hline
\end{tabular}

To gain an understanding of how people view both the arguments of economic impact and civic pride, the following five questions were asked in the Super Bowl questionnaire:

1. Do you know where this season's Super Bowl is going to be held?

2. Do you know where the last Super Bowl was held?

3. When a city hosts the Super Bowl does your interest in that city increase, decrease or remain the same?

4. Would the fact that a city has hosted a Super Bowl make you want to visit after the event?

5. Do you think professional sports teams improve the image of their host city?

The following six questions were asked in the Winter Olympics questionnaire:

1. Do you know where this year's Winter Olympics is going to be held?

2. Do you know where the 2010 Winter Olympics were held?

3. When a country hosts the Olympics does your interest in that country increase, decrease or remain the same?

4. Do you think hosting an Olympics improves the image of the host country?

5. Would the fact that a country hosted the Olympics make you want to visit that country after the event?

6. All things considered, was the decision to hold the 2014 Winter Olympics in Russia a good or bad decision?

Within each of these questions, we report the overall responses, as well as the responses broken down according to how closely sports are followed:

We found (Table 3A, 3B) that most people did not know where the Super Bowl was going to be held but they did know the location of the Winter Olympics (the Super Bowl was held in MetLife 
Table 3A: Answers (\%) to the question 'Do you know where this season's Super Bowl is going to be held?'

\begin{tabular}{llllll}
\hline & & & & & \\
& Follow sports... & & Not closely & Not at all \\
\cline { 2 - 4 } & All & Very closely & Somewhat closely & 16.9 & 8.3 \\
\hline
\end{tabular}

Table 3B: Answers (\%) to the question 'Do you know where this year's Winter Olympics is going to be held?'

\begin{tabular}{llllll}
\hline & & & & \\
& Follow sports... & Not closely & Not at all \\
\cline { 2 - 4 } & All & Very closely & Somewhat closely & 89.5 & 69.0 \\
\hline
\end{tabular}

Stadium at the Meadowlands, New Jersey, home of the New York Giants and New York Jets and the Winter Olympics in Sochi, Russia). We found that of people who follow sports very closely only 41 per cent could name the current year's Super Bowl host, while 96 per cent could name the host of the Winter Olympics. Our results suggest that trying to put a city in the spotlight using a sporting event does not always succeed unless it is a mega-event such as the Olympics. When it comes to the Super Bowl, we found that people tend to be unaware of, or pay little attention to, the city hosting the event. The Winter Olympics is such a major event that we found that nearly 70 per cent of people who do not follow sports still knew where the Winter Olympics were held.

We followed up by asking respondents whether they knew where the previous year's Super Bowl was held and where the previous Winter Olympics, in 2010, were held (the previous Super Bowl was held in the Superdome in New Orleans, and the 2010 Winter Olympics were held in Vancouver, Canada). We discovered (Table 4A, 4B) that the majority of people were unable to name the hosts of the previous Super Bowl or Winter Olympics, suggesting that the host city does not receive benefits from exposure that last over time. In fact, we discovered that less than half of individuals who self-identified as following sports very closely remembered where either the previous Super Bowl or Winter Olympics was held.

We asked respondents whether the hosting of a Super Bowl caused their interest in that city to increase, decrease, or remain the same. Most people said that hosting a Super Bowl did not change their opinion of that city (Table 5A). We found similar results for the Winter Olympics (Table 5B). When we focused only on the respondents who self-identified as following sports very closely, we

Table 4A: Answers (\%) to the question 'Do you know where the last Super Bowl was held?'

\begin{tabular}{llllll}
\hline & & & & & \\
& Follow sports... & Not closely & Not at all \\
\cline { 2 - 4 } & All & Very closely & Somewhat closely & 22 & 11.3 \\
\hline
\end{tabular}

Table 4B: Answers (\%) to the question 'Do you know where the 2010 Winter Olympics were held?'

\begin{tabular}{llllll}
\hline & & & & & \\
& Follow sports... & Not closely & Not at all \\
\cline { 2 - 6 } & All & Very closely & Somewhat closely & 25.8 & 11.3 \\
\hline
\end{tabular}


Table 5A: Answers (\%) to the question 'When a city hosts the Super Bowl does your interest in that city increase, decrease or remain the same?'

\begin{tabular}{|c|c|c|c|c|c|}
\hline & \multicolumn{5}{|c|}{ Follow sports... } \\
\hline & All & Very closely & Somewhat closely & Not closely & Not at all \\
\hline Increase & 22.8 & 30.1 & 26.8 & 26.7 & 12.3 \\
\hline Decrease & 2.1 & 0 & 3 & 2.8 & 1.9 \\
\hline Remain the same & 75.1 & 69.9 & 70.2 & 70.4 & 85.8 \\
\hline
\end{tabular}

Table 5B: Answers (\%) to the question 'When a country hosts the Olympics does your interest in that country increase, decrease or remain the same?'

\begin{tabular}{lcccrc}
\hline & \multicolumn{3}{c}{ Follow sports... } \\
\cline { 2 - 6 } & All & Very closely & Somewhat closely & Not closely & Not at all \\
\hline Increase & 34.1 & 47.2 & 35.7 & 30.6 & 17.3 \\
Decrease & 1.6 & 2.2 & 2.4 & 0.4 & 1.2 \\
Remain the same & 64.3 & 50.6 & 61.9 & 69.0 & 81.5 \\
\hline
\end{tabular}

found that less than half reported that the event increased their interest in the city. Most of the respondents reported that the event did not affect their interest in the city one way or the other.

In Table 6A and 6B, we show that there may be some residual economic impact. At least some people said they were more likely to visit a city after it had hosted a Super Bowl (18 per cent) and more likely to want to visit a country after an Olympics were held ( 24 per cent). Of course, we do not know whether these people would actually travel, but our results suggest that the events might increase some tourism.

We found (Table 7A, 7B) that 61 per cent of respondents believed that having a professional sports team improved the image of a city, while 63 per cent of respondents believed hosting an Olympics improved the image of a host country. When we focused only on people who did not follow sports at

Table 6A: Answers (\%) to the question 'Would the fact that a city has hosted a Super Bowl make you want to visit after the event?'

\begin{tabular}{|c|c|c|c|c|c|}
\hline & \multicolumn{5}{|c|}{ Follow sports... } \\
\hline & All & Very closely & Somewhat closely & Not closely & Not at all \\
\hline Yes & 17.5 & 30.1 & 23.8 & 16.7 & 5.3 \\
\hline No & 67.6 & 62.9 & 67.2 & 70.3 & 68.5 \\
\hline Don't know/refuse to answer & 14.9 & 7 & 9 & 13 & 26.2 \\
\hline
\end{tabular}

Table 6B: Answers (\%) to the question 'Would the fact that a country hosted the Olympics make you want to visit that country after the event?'

\begin{tabular}{|c|c|c|c|c|c|}
\hline & \multicolumn{5}{|c|}{ Follow sports... } \\
\hline & All & Very closely & Somewhat closely & Not closely & Not at all \\
\hline Yes & 23.6 & 38.2 & 23.9 & 15.5 & 16.7 \\
\hline No & 67.4 & 55.1 & 67.5 & 79.7 & 61.0 \\
\hline Don't know/refuse to answer & 9.0 & 6.7 & 8.6 & 4.7 & 22.2 \\
\hline
\end{tabular}


Table 7A: Answers (\%) to the question 'Do you think professional sports teams improve the image of their host city?'

\begin{tabular}{lccccc}
\hline & & \multicolumn{3}{c}{ Follow sports... } \\
\cline { 2 - 7 } & All & Very closely & Somewhat closely & Not closely & Not at all \\
\hline Yes & 60.9 & 74.4 & 73.4 & 56.2 & 45.5 \\
No & 24.3 & 19.4 & 16.7 & 30.4 & 29.7 \\
Don't know/refuse to answer & 14.7 & 6.2 & 9.9 & 13.4 & 24.8 \\
\hline
\end{tabular}

Table 7B: Answers (\%) to the question 'Do you think hosting an Olympics improves the image of the host country?'

\begin{tabular}{llllll}
\hline & & \multicolumn{3}{c}{ Follow sports... } \\
\cline { 2 - 6 } & All & Very closely & Somewhat closely & Not closely & Not at all \\
\hline Yes & 62.9 & 75.5 & 65.7 & 59.7 & 43.3 \\
No & 23.5 & 18.5 & 21.2 & 28.8 & 25.9 \\
Don't know/refuse to answer & 13.6 & 5.9 & 13.2 & 11.4 & 30.7 \\
\hline
\end{tabular}

Table 8: Answers (\%) to the question 'All things considered, was the decision to hold the 2014 Winter Olympics in Russia a good or bad decision?'

\begin{tabular}{lllll}
\hline & & & & Follow sports... \\
\cline { 2 - 5 } & All & Very closely & Somewhat closely & Not closely \\
Good & 48.2 & 59.5 & 57.6 & 38.6 \\
Bad & 25.7 & 29.3 & 21.7 & 30.3 \\
Don't know/refuse to answer & 26.1 & 11.1 & 20.7 & 31.1 \\
\hline
\end{tabular}

all, we found that 46 per cent and 43 per cent of them still believe that having a professional sports team enhanced the image of a city or hosting an Olympics enhanced the image of a country, respectively.

In Table 8wepresent the answers to the question: 'All things considered, was the decisiontohold the 2014 Winter Olympics in Russia a good or bad decision?' We discovered that 48 per cent of respondents believed hosting theWinter Olympicsin Russiawas a good idea. When focusing on how close arespondentfollows sports, we found that the majority of respondents who followed sports (very closely or somewhat closely) believed it was a good idea. A clear minority, however, of individuals who did not follow sports (not closely or not at all) believed it was a good idea. Although we do not know the criteriaindividuals use to decide why it is or is not agoodidea, we found that half the respondents were sceptical about the value of hosting the Olympics.

\section{Discussion}

The economics literature suggests that there are both short-term and long-term effects of hosting major events. The short-term impact is generated as the event happens while the long-term effects emerge after the event as the host city is in the world's spotlight. Some of the economic impact from a mega-event arises not just from those who travel there for the event, but from those who will travel to the city after the event is held as a result of the publicity. In our survey, we found that only 22 per cent of respondents knew where the next Super Bowl was being held (MetLife Stadium, northern New Jersey/New York) and 23 per cent knew where the last one was held (the Superdome, New Orleans). We found that of respondents who followed sports closely only 41 per cent could name the upcoming 
Super Bowl and only 36 per cent could name the previous Super Bowl, suggesting no long-term impacts.

Our results, however, differ for the Winter Olympics. We found that 87 per cent of respondents knew where the current Winter Olympics were held, but only 34 per cent knew where the previous Winter Olympics were held. Of the respondents who followed sports closely, 96 per cent knew where the Winter Olympics was just held but only 50 per cent could name the previous Winter Olympics. Given that the poll for the Winter Olympics was conducted days after the closing ceremony, whereas the Super Bowl poll was conducted months before the event date, this suggests that the fame from hosting a mega-event is very short-lived and does not lead to a long-term impact for either event.

When asked whether hosting the event increased their interest in the host city, only 23 per cent and 34 per cent of respondents, for the Super Bowl and Winter Olympics respectively, said 'yes'. When asked whether hosting a mega-event made them want to visit that city after the game, 68 per cent and 67 per cent of respondents said 'no' for the Super Bowl and Winter Olympics, respectively.

We did find, however, that 61 per cent of people surveyed believed that a professional sports team improved the image of a city, which is consistent with the results from the civic pride literature. The results are similar for the Winter Olympics, where 63 per cent of respondents believed that hosting an Olympics improved the image of the host country. These results suggest that individuals do feel civic pride from having a sports team or hosting a mega-event.

\section{Conclusion}

Our survey results of the general population in the United States show that the majority of respondents believe that sports teams or mega-events do not generate a local economic impact. The great bulk of the economics literature also concludes that having a professional sports team or hosting a major event does not generate a local economic impact. Our survey's results are consistent with the findings of the economics literature on the effects of mega-events such as the Super Bowl or the Winter Olympics on creating an economic impact on the host's economy.

We find that both the general public and the researchers do not expect an economic impact from hosting the Super Bowl or Olympics that is beneficial to a local area. In addition, the bulk of the economics literature on civic pride concludes that sports teams and events do generate intangible public good benefits, although the benefits fall short of the costs of fully publicly subsidised teams or events. Our survey also finds that the public agree that sports teams and events do create civic pride benefits. Our research suggests that the general public has become sceptical about the use of public funds to build sports stadiums or host mega-events.

\section{Notes}

1. The Seaton Hall Sports Poll may be found at http://www.shu.edu/academics/business/sports-polling/index.cfm. The page on poll methodology advises that 'The error due to sampling for results based on the entire sample could be plus or minus 3.5 percentage points. The error for subgroups may be higher. This poll release conforms to the Standards of Disclosure of the National Council on Public Polls.'

2. Calls are automatically made from a list of known phone numbers for residents in the United States. Calls with no answer, or callers who are not willing to answer survey questions, are listed as non-responses. The low response rate reflects the large number of unanswered phones rather than the randomness of the dialing process. 


\section{References}

Agha, N. (2013) 'The Economic Impact of Stadiums and Teams: The Case of Minor League Baseball', J ournal of Sports Economics 14(3), 227-52.

Allmers, S. and W. Maennig (2009) 'Economic Impacts of the FIFA Soccer World Cups in France 1998, Germany 2006, and Outlook for South Africa 2010', Eastern Economic J ournal 35, 500-19.

Atkinson, G., S. Mourato, S. Szymanski and E. Ozdemiroglu (2008) 'Are We Willing to Pay Enough to "Back the Bid"?: Valuing the Intangible Impacts of London's Bid to Host the 2012 Summer Olympic Games', Urban Studies 45, 419-44.

Baade, R. A. (1996) 'Professional Sports as Catalysts for Metropolitan Economic Development', J ournal of Urban Affairs18(1),1-17.

Baade, R. A. and R. F. Dye (1988) 'An Analysis of the Economic Rationale for Public Subsidization of Sports Stadiums', TheAnnals of Regional Sciences22(2), 37-47.

Baade, R. A. and R. F.Dye (1990) 'The Impact of Stadiums and Professional Sports on Metropolitan Area Development', GrowthandChange21(2),1-14.

Baade, R. A. and V. Matheson (2004) 'The Quest for the Cup: Assessing the Economic Impact of the World Cup', Regional Studies 28(4), 345-54.

Baade, R. A. and A. R. Sanderson (1997) 'The Employment Effect of Teams and Sports Facilities', in R. G. Noll and A. Zimbalist (eds), Sports, J obsand Taxes: TheEconomicImpact of Sports Teamsand StadiumsWashington, DC: Brookings Institution.

Burns, E. B. (2014) 'When the Saints Went Marching In: Social Identity in the World Champion New Orleans Saints Football Teamand Its Impacton Their HostCity',J ournal of Sportsand SocialIssues38(2), 148-63.

Carlino, G. and N. E. Coulson (2004) 'Compensating Differentials and the Social Benefits of the NFL', J ournal of Urban Economics 56(1), 25-50.

Coates, D. and C. A. Depken (2009) 'The Impact of College Football Games on Local Sales Tax Revenue: Evidence from Four Cities in Texas', Eastern Economic J ournal 35, 531-47.

Coates, D. and B. R. Humphreys (2003) 'The Effect of Professional Sports on Earnings and Employment in the Services and Retail Sectors in US Cities', Regional Scienceand Urban Economics 33, 175-98.

Coates, D., B. R. Humphreys and A. Zimbalist (2006) 'Compensating Differentials and the Social Benefits of the NFL: A Comment', J ournal of Urban Economics 60(1), 124-131.

Coates, D. and V. Matheson (2011) 'Mega-events and Housing Costs: Raising the Rent While Raising the Roof?', The AnnalsofRegionalScience46(1),119-37.

Crompton, J. L. (1995) 'Economic Impact Analysis of Sports Facilities and Events: Eleven Sources of Misapplication', J ournal of Sport Management9, 14-35.

Dohmen, T. J., A. Falk, D. Huffman and U. Sunde (2006) Seemingly Irrelevant Events Affect Economic Perceptions and Expectations: The FIFA World Cup 2006 as a Natural Experiment. IZA Discussion Paper No. 2275. Bonn: Institute for the Study of Labor (IZA). https://www.cens.uni-bonn.de/team/board/armin-falk/1seeminglyirrelevant-events-affect-economic-perceptions-and-expectations-the-fifa-world-cup-2006-as-a-natural-experimentiza-dp-2275-with-thomas-dohmen-david-huffman-and-uwe-sunde..pdf (accessed 1 December 2015).

Eckstein, R. and K. Delaney (2002) 'New Sports Stadiums, Community Self-Esteem, and Community Collective Conscience', J ournal of Sportsand Social Issues26(3), 235-47.

Fenn, A. J. and J. R. Crooker (2009) 'Estimating Local Welfare Generated by an NFL Team under Credible Threat of Relocation', SouthernEconomicJ ournal76(1),198-223.

Groothuis, P.A., B. Johnson and J. C. Whitehead (2004) 'Public Funding for Professional Sports Arenas: Civic Pride or Public Choice', Eastern EconomicJ ournal 30(4), 515-26.

Hagn, F. and W. Maennig (2008) 'Employment Effects of the Football World Cup 1974 in Germany', Labour Eoonomics 15(5), 1062-75.

Hagn, F. and W. Maennig (2009) 'Large Sport Events and Unemployment: The Case of the 2006 Soccer World Cup in Germany', Applied Economics 41(25), 3295-302.

Hudson, I. (2001) 'The Use and Misuse of Economic Impact Analysis: The Case of Professional Sports', J ournal of Sports and Social Issues 25(1), 20-39.

Jasina, J. and K. W. Rotthoff (2008) 'The Impact of a Professional Sports Franchise on County Employment and Wages', International J ournal of Sport Finance 3(4), 210-27.

Johnson, B. K. and J. C. Whitehead (2000) 'Value of Public Goods From Sports Stadiums: The CVM Approach', Contemporary Economic Policy 18(1), 48-58.

Johnson, B., P. A. Groothuis and J. C. Whitehead (2001) 'The Value of Public Goods Generated by a Major League Sports Team:The CVM Approach',J ournal of SportsEconomics2(1), 6-21.

Johnson, B., M. J. Mondello and J. C. Whitehead (2007) 'The Value of Public Goods Generated by a National Football League Team',J ournal of SportManagement21(1),123-36. 
Kavetsos, G. and S. Szymanski (2008) National Wellbeing and International Sports Events. North American Association of Sports Economists Working Paper No. 08-04. Available at http://college.holycross.edu/RePEc/spe/ SzymanskiKavetsos_WellBeing.pdf (accessed 1 December 2015).

Owen, J. (2006) 'The Intangible Benefits of Sports Teams', Public Finance \& Management 6(3), 321-45.

Preuss, H. (2007) 'The Conceptualisation and Measurement of Mega-Sport Event Legacies', J ournal of Sport and Tourism 12(3-4), 207-27.

Preuss, H. (2011) 'A Method for Calculating the Crowding-Out Effect in Sport Mega-event Impact Studies: The 2010 FIFA World Cup', Development Southern Africa 28(3), 367-85.

Ritchie, J. R. and B. H. Smith (1991) 'The Impact of a Mega-Event on Host Region Awareness: A Longitudinal Study', J ournal of Travel Research 30(1), 3-10.

Santo, C. (2005) 'The Economic Impact of Sports Stadiums: Recasting the Analysis in Context', J ournal of Urban Affairs 27(2), 177-92.

Soberg, H. and H. Preuss (2007) ‘Major Sport Events and Long-Term Tourism Impacts', J ournal of Sport Management 21, 213-34.

Szymanski, S. (2002) 'The Economic Impact of the World Cup', World Economics 3(1), 1-10.

Teigland,J.(1999) 'Mega-eventsandImpacts on Tourism: ThePredictionsandRealities of the Lillehammer Olympics', Impact Assessment and Project Appraisal 17, 305-17.

Walton, H., A. Longo and P. Dawson (2008) 'A Contingent Valuation of the 2012 London Olympic Games: A Regional Perspective',J ournal of SportsEconomics9(3), 304-17.

Whitehead, J. C., B. K. Johnson, D. S. Mason and G. J. Walker (2013) 'Consumption Benefits of National Hockey League Game Trips Estimated From Revealed and Stated Preference Demand Data', Economic Inquiry 51, 1012-25.

Zimbalist, A. and R. G. Noll (1997) 'Sports, Jobs, and Taxes: Are New Stadiums Worth the Cost?', in R. G. Noll and A. Zimbalist (eds), Sports,J obsand Taxes: TheEconomicImpactof Sports Teamsand Stadiums. Washington, DC: Brookings Institution. 